\title{
Seasonal Distribution of Sharp-beaked Redfish (Sebastes spp.) in Northeastern Grand Bank
}

\author{
D. B. Atkinson \\ Department of Fisheries and Oceans, Science Branch \\ P. O. Box 5667, St. John's, Newfoundland, Canada A1C 5X1
}

\begin{abstract}
Sharp-beaked redfish (Sebastes spp.) are distributed widely in northeastern Grand Bank, NAFO Div. 3L, during all of the year. There appears to be a partial separation between northern and southern distribution in the vicinity of $47^{\circ} 15^{\prime} \mathrm{N}$ for all but the third quarter of the year. They move westward along and up the continental slope between the second and third quarters then back easterly during the fourth and first. There may also be some movement between the northern part of the Division and more northern waters (Div. 3K) during the year. The redfish are distributed deepest during the second quarter, then they move into shallower waters in the third quarter before beginning to move deeper again in the fourth and first quarters. Females predominate at depths of $400-449 \mathrm{~m}$ during the first quarter and $250-349 \mathrm{~m}$ during the third. There is very little geographic separation of the sexes in the second and fourth quarters. The largest fish are generally found in intermediate depths, associated with bottom temperatures of about $2.0^{\circ}$ to $4.9^{\circ} \mathrm{C}$.
\end{abstract}

\section{Introduction}

Sharp-beaked redfish (Sebastes spp.) exhibit seasonal changes in their distribution which may represent behaviorial responses associated with mating (Magnússon, 1961) larval extrusion (Magnússon, 1961; Soroken, 1961; Sidorenko, MS 1966; Chekova, 1972) and feeding (Sidorenko, MS 1966). Nikolskaya (1973) and Atkinson (1984) also described seasonal changes in redfish distribution, but did not elucidate possible causes. Knowledge of these changes is important, not only from a biological point of view, but also for the successful prosecution of fisheries.

In the Northwest Atlantic, sharp-beaked redfish (Sebastes mentella and S. fasciatus) (hereinafter referred to as redfish) are generally found in depths $>200 \mathrm{~m}$. Trawl surveys have been carried out for redfish as well as other groundfish species by the Newfoundland Region of the Department of Fisheries and Oceans, Government of Canada, from the late-1950s to the present. Beginning in the early-1970s, these surveys have been conducted in a particular area at about the same time each year in order to remove possible effects of seasonal variability in fish distribution on estimates of abundance and biomass. Because of this, little information is available concerning seasonality in the distribution of redfish and other species inhabiting depths $>200 \mathrm{~m}$. Only in Div. 3L, northeastern Grand Bank, has fairly extensive research trawling taken place at depths beyond $200 \mathrm{~m}$ in all four quarters of the year. $\mathrm{Ni}$ (1981) showed that the two species of redfish reside in Div. 3L. Because the existence of the two species was either unknown or only hypothesized during much of the data collection time period, and because separation can only be achieved through dissection (Ni, 1981) or the use of biochemical techniques (Payne and $\mathrm{Ni}$, 1982), this paper describes the seasonal pattern of distribution of these redfish in Div. $3 \mathrm{~L}$ by depth, temperature and geography.

\section{Materials and Methods}

From 1958 to 1987, a total of 1,419 successful (no net damage) $30 \mathrm{~min}$. sets were made in surveys conducted by the Newfoundland Region of the Department of Fisheries and Oceans, Government of Canada, in Div. 3L at depths of $200 \mathrm{~m}$ and greater (Fig. 1). Either a Yankee 41-5 trawl or an Engel 145 High Lift trawl (Table 1) with a $25 \mathrm{~mm}$ liner inside the codend was used for all fishing sets. Besides recording the catch as numbers

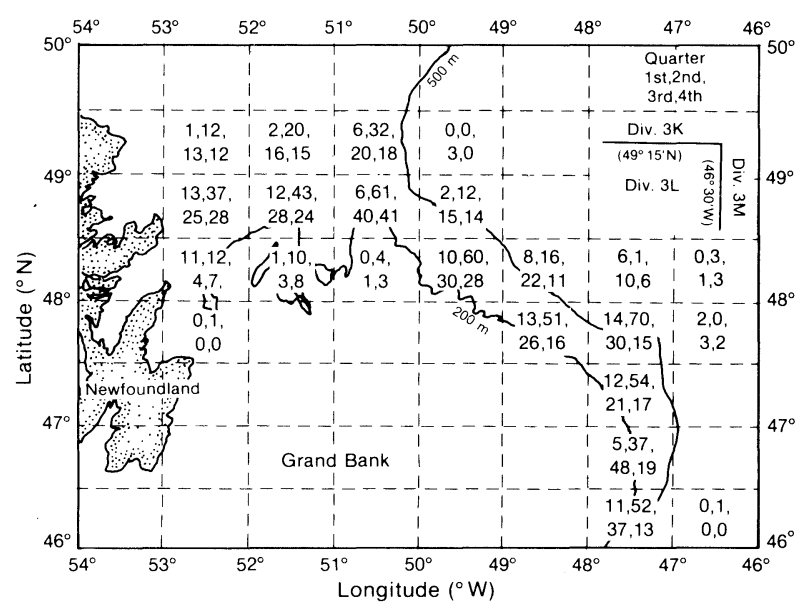

Fig. 1. Map of NAFO Div. 3L showing number of successful sets made in each half degree latitude by one degree longitude unit area in each quarter (1958-87) 
TABLE 1. Dimensions $(m)$ of the trawls used during trawling surveys in NAFO Div. 3L (adapted from Carrothers, MS 1974).

\begin{tabular}{lcc}
\hline \hline Dimensions & Yankee 41-5 & Engel 145 \\
\hline Headline & 24.4 & 29.3 \\
Footrope & 30.5 & 44.2 \\
Length & 35.0 & 41.2 \\
Mouth height & $2.4-3.4$ & $4.9-6.7$ \\
Mouth width & 13.4 & 15.2 \\
\hline
\end{tabular}

and weights, length frequencies by sex were collected for each set. Fish $<15 \mathrm{~cm}$ were not sexed.

Only sets made at depths $>199$ m were included in the analyses because most often no redfish were taken in shallower waters during the entire period under study. No adjustments for catchability differences between the two gears were made. It was probable, however, that the abundance of redfish in the study area had changed over the period of data collection and to eliminate any effects this may have on the results, catches (numbers and weights $(\mathrm{kg})$ ) in each year were first standardized to the mean value calculated for that year (herein referred to as standardized catch numbers and weights). Thus, catches in all years have equal weighting regardless of abundance changes.

Data from successful sets were analyzed separately by quarter year periods (January-March being first quarter, April-June the second, July-September the third, and October-December the fourth). The quarterly catch data were examined by one-half degree latitude by one degree longitude unit areas and the mean standardized numbers and weights of redfish caught in each unit area calculated. For those unit areas lying partially outside the boundary of Div. 3L, only sets from within the Division were used. These standardized catch numbers and weights data were also averaged by $50 \mathrm{~m}$ bottom depth intervals based on mean bottom depth during trawling, and $1.0^{\circ} \mathrm{C}$ bottom temperature (measured by Nansen bottle until 1978 and expendable bathythermograph (Sipican Corp.) thereafter) intervals (Table 2). These intervals were selected so that there would be at least one set in each range in each quarter. Mean depth and mean temperature associated with each temperature and depth range respectively were also calculated.
Kolmogorov-Smirnov two-tailed analyses (Siegel, 1956) were carried out in pairs to test the null hypothesis that the distribution of catch (mean standardized numbers and weight-per-tow) of redfish across the different depth ranges did not change with quarterly periods. The mean standardized catch values were converted to percent of the sum-of-means prior to this analysis to remove any effects of different overall catches in the different quarters.

The sex ratio taking only fish $<14 \mathrm{~cm}$ in each depth range was determined by quarter, then weighted by catch numbers in each depth range in the corresponding quarter. Finally, length frequencies (fork length to the nearest $\mathrm{cm}$ ) of mean numbers caught-per-tow (sexes separated) were examined by both depth and temperature ranges for the different quarters.

\section{Results}

The mean depth for each temperature range changed only slightly, up to about $1.0^{\circ} \mathrm{C}$ (Fig. 2A).
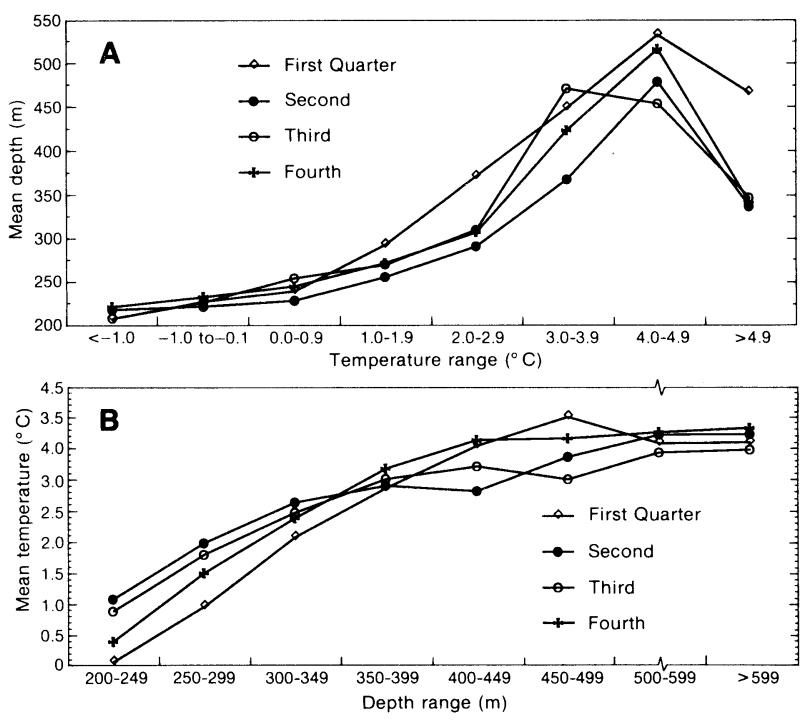

Fig. 2. Mean depth in each temperature range (A) and mean temperature in each depth range $(\mathbf{B})$ by quarter during research trawls in NAFO Div. 3L (1958-87).

TABLE 2. Number of successful $30 \mathrm{~min}$. sets by depth range $(\mathrm{m})$ and temperature range $\left({ }^{\circ} \mathrm{C}\right)$ in each quarter of the year in NAFO Div. 3L.

\begin{tabular}{|c|c|c|c|c|c|c|c|c|c|}
\hline \multirow{2}{*}{$\begin{array}{l}\text { Depth } \\
\text { range } \\
(\mathrm{m})\end{array}$} & \multicolumn{4}{|c|}{ Number of successful sets } & \multirow{2}{*}{$\begin{array}{c}\text { Temperature } \\
\text { range } \\
\left({ }^{\circ} \mathrm{C}\right)\end{array}$} & \multicolumn{4}{|c|}{ Number of successful sets } \\
\hline & $\begin{array}{c}\text { First } \\
\text { quarter }\end{array}$ & $\begin{array}{l}\text { Second } \\
\text { quarter }\end{array}$ & $\begin{array}{l}\text { Third } \\
\text { quarter }\end{array}$ & $\begin{array}{l}\text { Fourth } \\
\text { quarter }\end{array}$ & & $\begin{array}{c}\text { First } \\
\text { quarter }\end{array}$ & $\begin{array}{l}\text { Second } \\
\text { quarter }\end{array}$ & $\begin{array}{l}\text { Third } \\
\text { quarter }\end{array}$ & $\begin{array}{l}\text { Fourth } \\
\text { quarter }\end{array}$ \\
\hline $200-249$ & 46 & 246 & 103 & 87 & $<-1.0$ & 1 & 5 & 1 & 7 \\
\hline $250-299$ & 33 & 125 & 70 & 59 & -1.0 to -0.1 & 25 & 38 & 37 & 34 \\
\hline $300-349$ & 33 & 172 & 88 & 75 & 0.0 to 0.9 & 32 & 74 & 33 & 39 \\
\hline 350-399 & 7 & 24 & 31 & 16 & 1.0 to 1.9 & 33 & 152 & 58 & 51 \\
\hline $400-449$ & 7 & 6 & 20 & 13 & 2.0 to 2.9 & 18 & 214 & 117 & 61 \\
\hline $450-499$ & 9 & 8 & 17 & 8 & 3.0 to 3.9 & 31 & 102 & 128 & 59 \\
\hline $500-549)$ & $E$ & 0 & 20 & 10 & 4.0 to 4.9 & 5 & 7 & 5 & 15 \\
\hline $550-599\}$ & 5 & 8 & 32 & 10 & $>4.9$ & 2 & 1 & 1 & 2 \\
\hline$>599$ & 8 & 10 & 30 & 13 & Missing & 1 & 6 & 11 & 13 \\
\hline
\end{tabular}


Temperatures above this were generally found deeper in the first and fourth quarters than in the second and third. Temperatures above $4.9^{\circ} \mathrm{C}$ were not encountered frequently. Mean temperature in each depth range (Fig. 2B) indicated that some changes occurred over the four seasons. At depths from 200 to about $350 \mathrm{~m}$, cooler temperatures prevailed in the first quarter with warmer water present in the second and third quarters. Temperatures again declined somewhat in the fourth quarter. From about 400 to $500 \mathrm{~m}$, on average the water was warmer in the first and fourth quarters than in the second and third.

Number of successful sets in Div. 3L at depths $>199 \mathrm{~m}$ and entire temperature range (Table 2) were widely distributed in all four quarters (Fig. 1). The dis- tribution of redfish by standardized numbers and weights was similar (Fig. 3 and 4 ) and indicated that they occurred all along the edge of the continental shelf. There was an indication of movement along the northeast slope during the year, westerly from the first to third quarters, then back to the east in the fourth. There may also have been some movement between Div. $3 \mathrm{~K}$ and Div. $3 \mathrm{~L}$ during the year. Except for the third quarter, there seemed to be a separation (at approximately $47^{\circ} 15^{\prime} \mathrm{N}$ ) between concentrations found on the southeastern slope and in the northeastern area.

The distribution of redfish shown as standardized numbers (Fig. 5A) with depth (Fig. 5B), indicates movement between deeper and shallower waters at different times of the year (Table 3). They were predominantly at

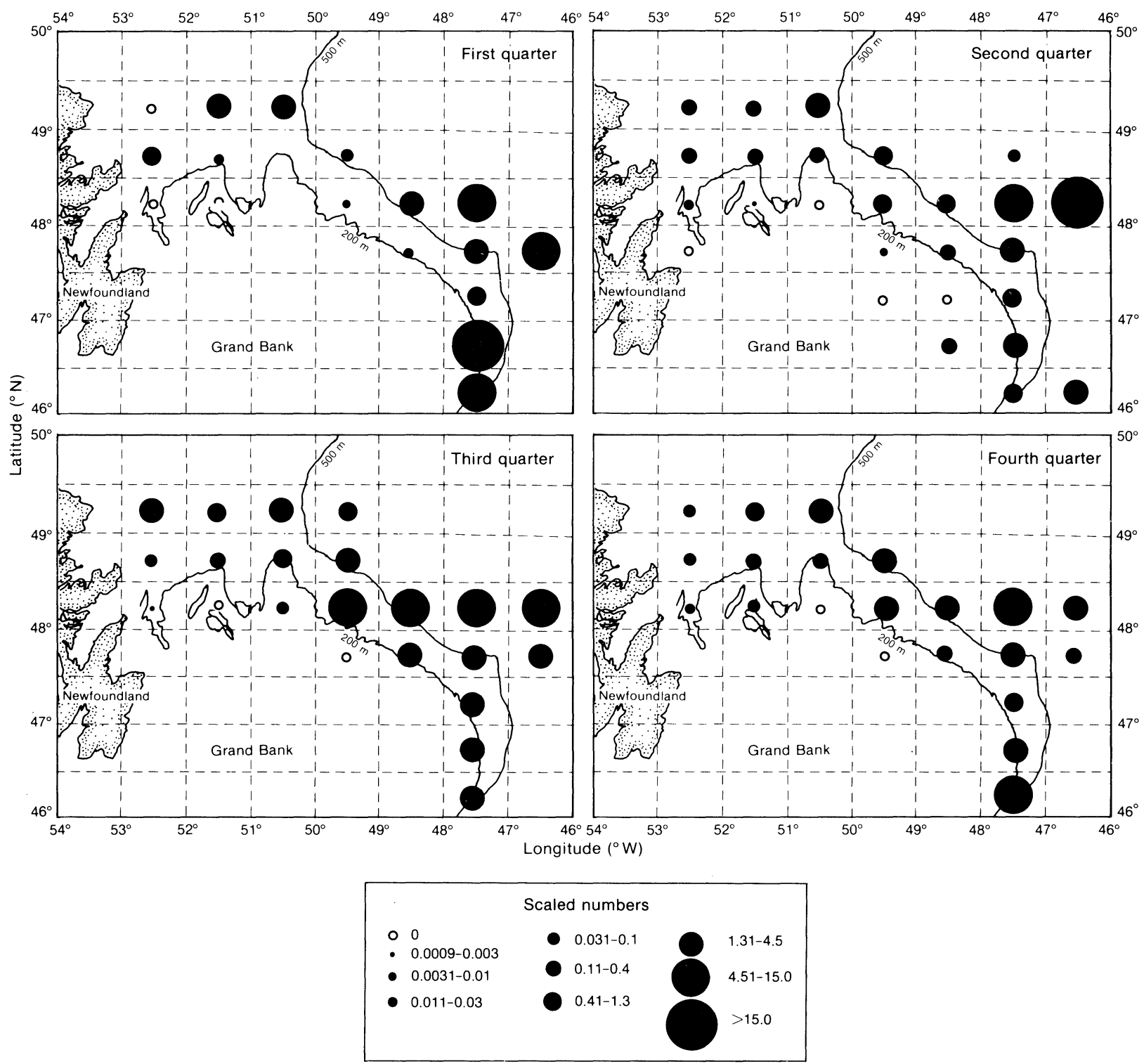

Fig. 3. Mean catches as standardized numbers of beaked redfish per standard tow in each unit area in each quarter in NAFO Div. 3L. 

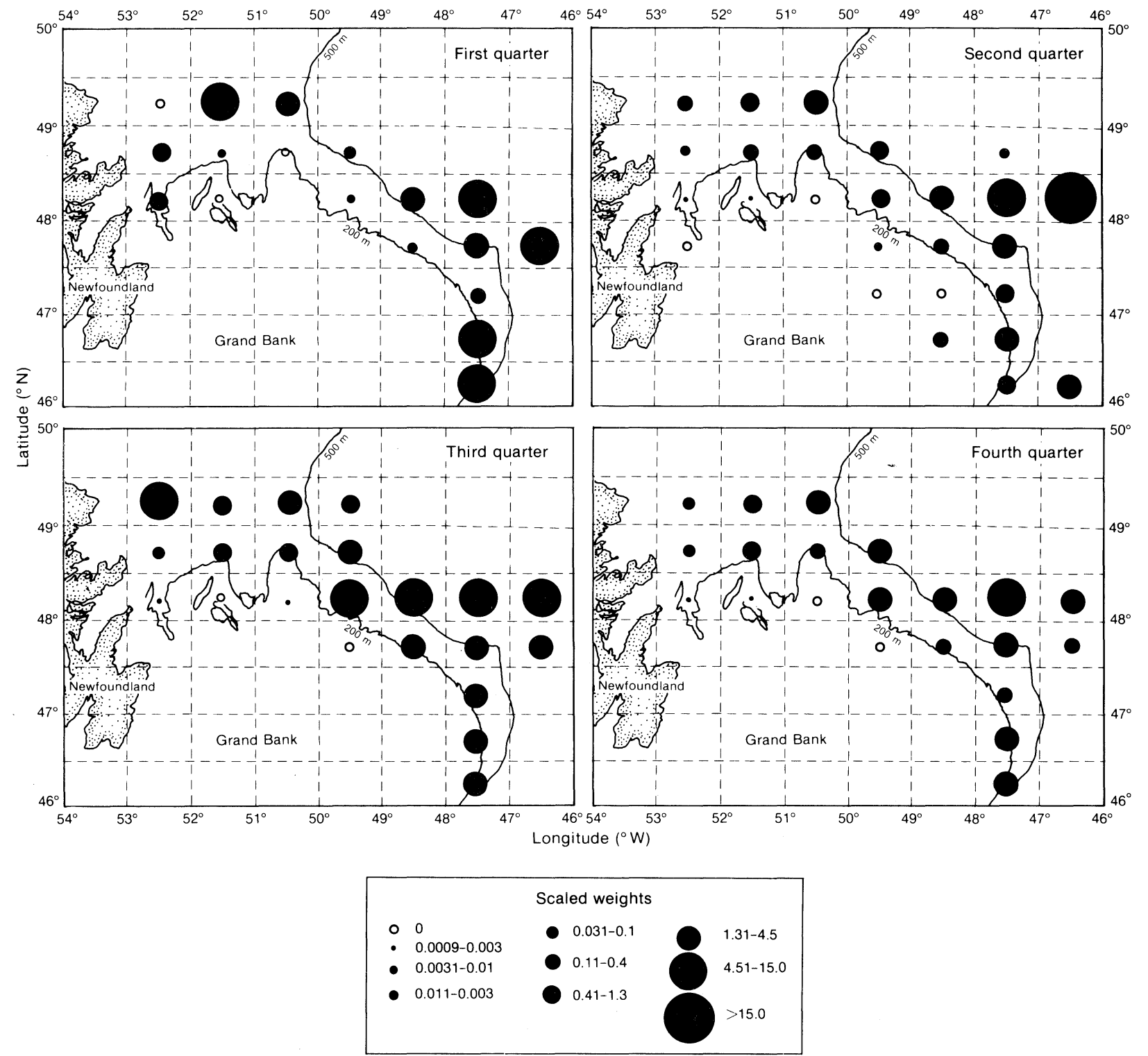

Fig. 4. Mean catches as standardized weights of beaked redfish per standard tow in each unit area in each quarter in NAFO Div. $3 \mathrm{~L}$.

depths $>500 \mathrm{~m}$ during the second quarter, then spread into a wide range of depths in the third quarter. In the fourth and first quarters, the fish were distributed in intermediate depth ranges, between about 300 and 500 $\mathrm{m}$. There was an indication that they were gradually moving deeper between the fourth and first quarters. The distributions with depth in all four quarters were significantly different from one another $(P<0.05)$ (Table 3).

The sex ratios were somewhat different at different depths in the four quarters (Fig. 6). Females predominated the 450-499 m depth range during the first quarter while males predominated the shallower and deeper waters. In the third quarter, females were found in shal- lower waters than males and predominating the 250-349 $\mathrm{m}$ range. During the second and fourth quarters, there was less separation of the sexes. Overall, females accounted for about $50 \%$ of the total population.

The length frequencies (Fig. 7 and 8) show that when present, redfish $<15 \mathrm{~cm}$ were primarily located in water shallower than about $350 \mathrm{~m}$, and in water temperatures $0.0^{\circ}$ to $0.9^{\circ} \mathrm{C}$. Larger fish were not abundant at any time in temperatures $<2^{\circ} \mathrm{C}$. Relatively high numbers of fish were caught in the few sets made in temperatures $>4.9^{\circ} \mathrm{C}$, especially in the first and second quarters. Later in the year, they were distributed in cooler shallower waters. The largest fish were gener- 


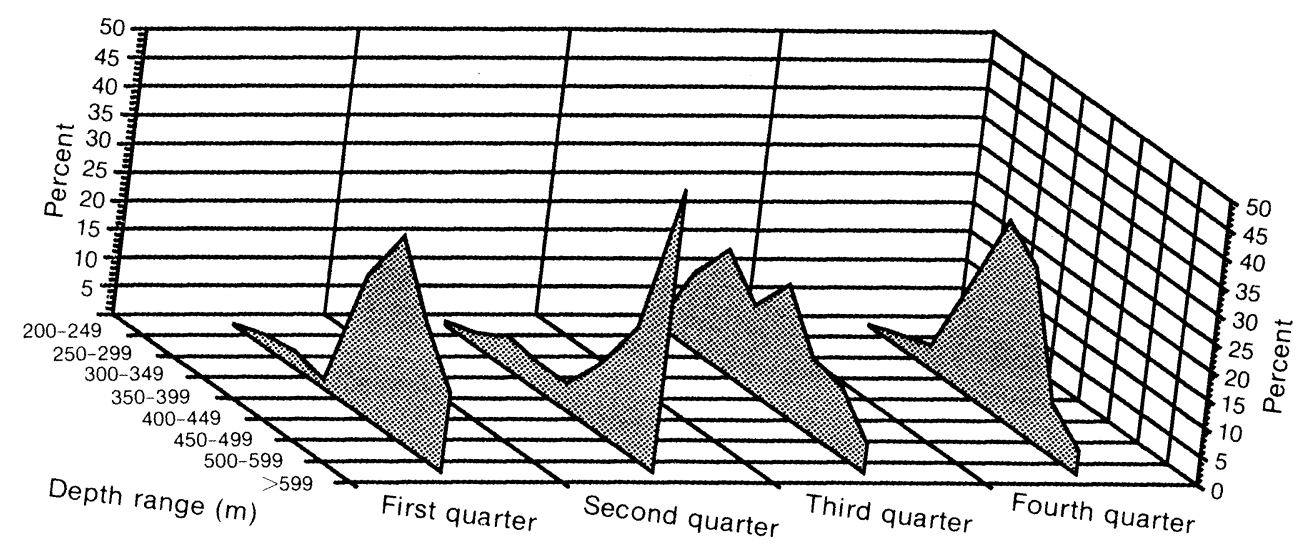

\section{B. Weight}

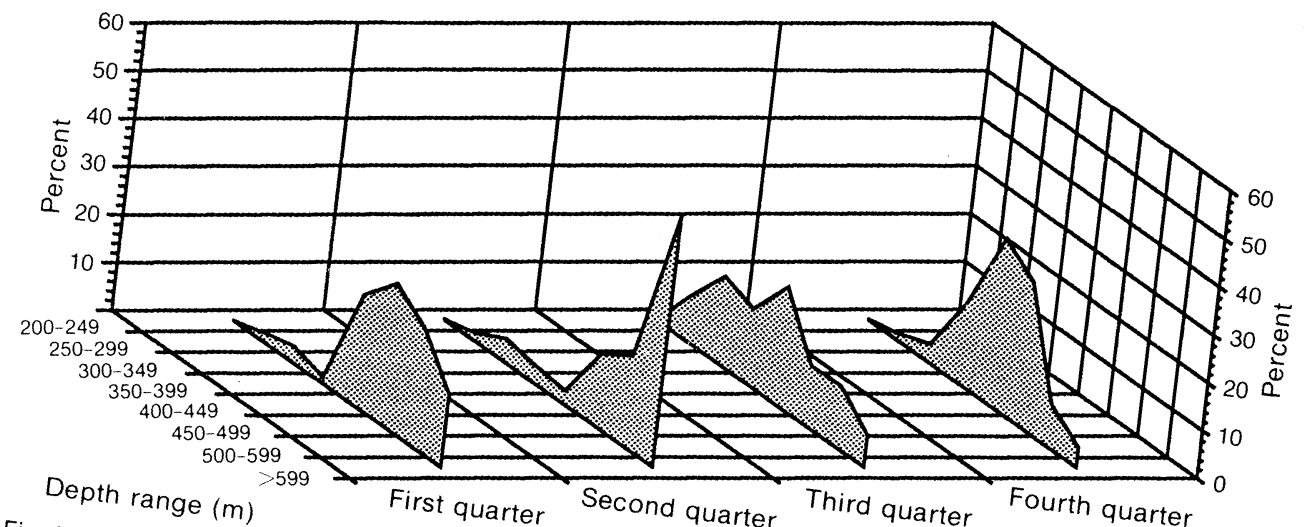

Fig. 5. Mean $(\mathrm{m})$

Mean catches as standardized numbers
standard tow by depth range expressed

Results of the Kolmogorov-Smirnd

cent.

(B) of beaked redfish per

tribution of redfimogorov-Smirnov analysis (Seiget, 1956$)$

significant).

\begin{tabular}{|c|c|c|c|c|c|c|c|c|}
\hline & & & & & & & two & $\begin{array}{l}\text { in the di } \\
\text { esults ar }\end{array}$ \\
\hline $\begin{array}{l}\text { Numbers/weight } \\
\text { First quarter } \\
\text { Second quarter }\end{array}$ & $z$ & $p$ & $\frac{\mathrm{se}}{z}$ & Second quarter & \multicolumn{2}{|c|}{ Third quarter } & & \\
\hline Second quarter & - & - & $\frac{2}{2630}$ & $p$ & $z$ & & \multicolumn{2}{|c|}{ Fourth quarter } \\
\hline $\begin{array}{l}\text { Third quarter } \\
\text { Eourth quarter }\end{array}$ & $\begin{array}{l}2.517 \\
3.041\end{array}$ & $<0.001$ & $\begin{array}{r}2.639 \\
-\end{array}$ & $<0.001$ & 2.689 & $p$ & $z$ & $p$ \\
\hline cin quarter & 2.051 & $\begin{array}{l}<0.001 \\
<0.001 \\
\end{array}$ & $\begin{array}{l}3.919 \\
4.132\end{array}$ & $<0.001$ & $\begin{array}{r}3.799 \\
-\end{array}$ & $\begin{array}{l}<0.001 \\
<0.001\end{array}$ & 1.989 & 0.001 \\
\hline & & & & $<0.001$ & $1.9 \overline{80}$ & $0.0 \overline{1}$ & $\begin{array}{r}4.151 \\
1.478 \\
-\end{array}$ & $\begin{array}{r}<0.001 \\
0.025\end{array}$ \\
\hline
\end{tabular}

intermediate temperatures $\left(20^{\circ}\right.$, asssociated with much nistrion of the fish found $\left(2.0^{\circ}\right.$ to $\left.4.9^{\circ} \mathrm{C}\right)$. The length fourth quarter. than that in cooler waters $>4.9^{\circ} \mathrm{C}$ was as evidenced. Females were much taters in all but the length of both many of the frequen larger than males with depth only males and females incies. The mean first quarter found from 250 larger fish, particularly. 9). During the 250 to $400 \mathrm{~m}$. There was fittlemales were as little indication of any increase in temperature except fish length with increasing water during the fourth quarter (Fig. 10).

\section{Discussion}

Redfish exhibit

the slope of the continental movements up and down Northeast Atlantic 1966) also found that. Marti (1962) 


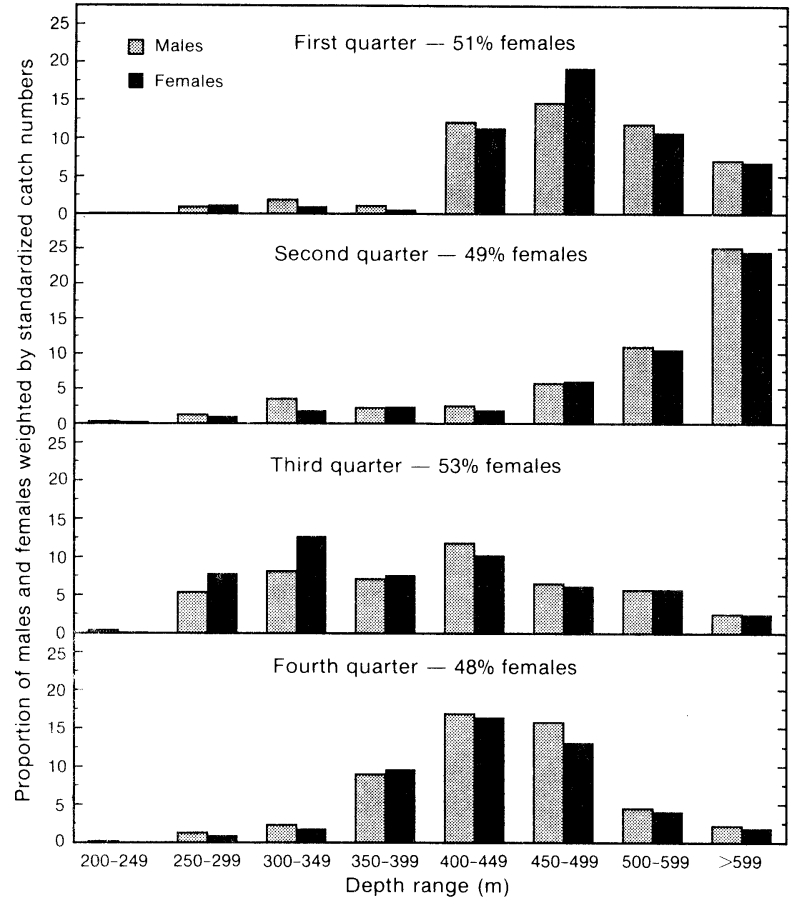

Fig. 6. Proportions of male and female beaked redfish in each depth range in each quarter in NAFO Div. $3 L$ weighted by standardized catch numbers.

the summer and Atkinson (1984) showed a movement to deeper waters during the winter in the Gulf of St. Lawrence. Minet (MS 1975) reported that redfish biomass was greatest at 200-350 m depths in summer but moved to depths $>350 \mathrm{~m}$ during the winter in Div. 3P.

In Div. 3L, redfish were found deepest during the second quarter of the year, a time corresponding to larval release from April to June. This is in contrast to reported movements of females to shallower water during larval release (Sandeman, MS 1956; Sidorenko, MS 1966). Chekova (1972), however, found that large females moved deeper to spawn on the Flemish Cap, and Templeman (1976) found female S. mentella with the more developed ovaries in deep water (455-530 m) and relatively few mature females shallower in the same area. Chekova (1972) also noted that after larval release females immediately move to shallower water, similar to the findings of this study. The similarity is also drawn to the Pacific ocean perch which is noted to move to deeper waters to release larvae in March and then back to shallower waters for feeding (Gunderson, 1971).

Chekova and Konstantinov (1978) concluded that females spawn in the pelagic zone of the Flemish Cap, moving up in the water column in March and returning to the bottom by July. This type of movement would result in a change in the sex ratio of bottom trawl catches during the second quarter of the year, but the present study indicated no such change in Div. 3L.
Instead, a fairly constant female/male ratio was observed in all four quarters of the year. The apparent coming together of the two sexes in the fourth quarter is probably related to mating, whereas the lack of separation in the second quarter is reflective of most of the population being concentrated in deeper water. In the Northeast Atlantic, mating occurs during OctoberJanuary (Magnússon, 1955), and $\mathrm{Ni}$ and Templeman (1985) concluded that in the Northwest Atlantic, copulation takes place during the same period.

It has been generally considered that redfish distribution is stratified in size by depth (e.g. Perlmutter, 1953; Schroeder, 1955; Templeman, 1955, 1957, 1959), that is, larger fish are found in deeper waters. The results of this study indicate that this stratification is only maintained in the fourth quarter (and to a lesser extent in the third) in Div. $3 L$ and the mean size of the fish is variable with depth in the first and second quarters. During the first quarter, larger females were more often found at 250-449 $\mathrm{m}$ than deeper, while males were fairly evenly distributed by size over all depth ranges. Chekova (1972) also found seasonal differences in size stratification with depth between sexes and seasons on Flemish Cap, but the variations were different to those noted in this study.

Templeman (1959) concluded that redfish in the Northwest Atlantic are most abundant in water temperatures from about $3^{\circ}$ to $6^{\circ} \mathrm{C}$. Atkinson (1984) found redfish to be abundant in temperatures of $2^{\circ}$ to $7^{\circ} \mathrm{C}$ in the Gulf of St. Lawrence and noted that the deeper water to which they moved in the winter was also warmer, similar to the results of this study. It is not known whether these seasonal movements are driven by some depth related phenomenon per se, temperature, or some other factor.

Travinet al. (1961) reported that redfish in northern Div. 3L were similar to those in Div. $3 \mathrm{~K}$ and also suggested that there was intermingling of redfish in southern Div. 3L and northern Div. 3N. The data available for this study were insufficient to determine if there is any lateral movement along the shelf, but the changes in abundance in the areas north of $48^{\circ} 30^{\prime} \mathrm{N}$ suggest a possible north-south movement between Div. $3 \mathrm{~K}$ and Div. 3L. The apparent separation (except in the third quarter) of concentrations on the southeastern and northwestern slopes may also be meaningful with regard to a north-south separation of groups. Any movement between Div. $3 \mathrm{~K}$ and $3 \mathrm{~L}$ as well as a separation between redfish on the southeast and northwest slopes would have significant implications with regard to management of these fish, as the Div. $3 \mathrm{~K} / 3 \mathrm{~L}$ boundary currently separates two adjacent management units (NAFO Subarea $2+$ Div. 3K and Div. 3LN). Further studies are needed to investigate if any realignment of management units is necessary in this area. 

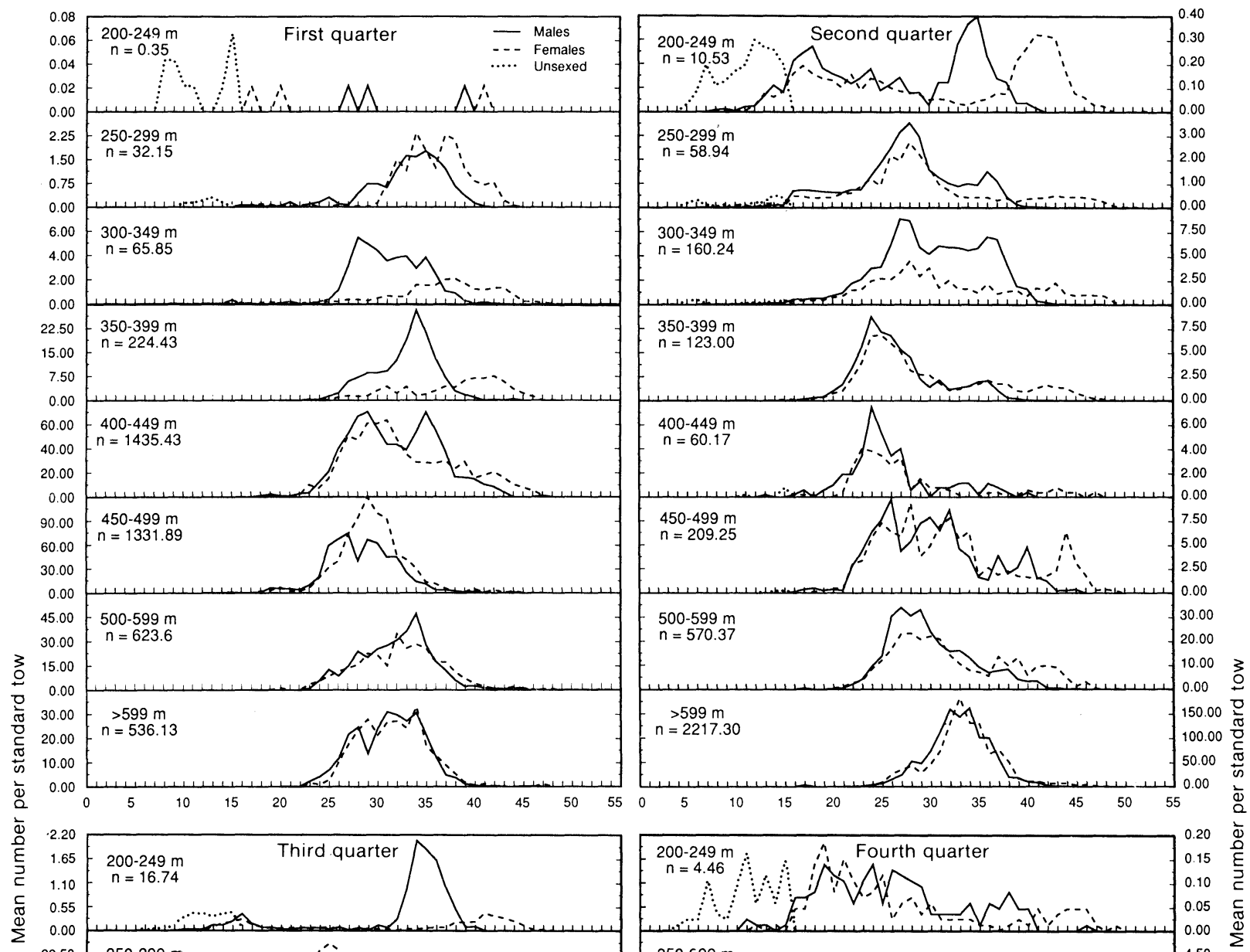

15.00

0.0

60.00

40.00

0.00

22.50
15.00

15.00
7.50

0.00
30.00

30.00
20.00

20.00

0.00

22.50
15.00

15.00
7.50

0.00

$n=459.01$

300-349 m

$n=886.03$

350-399 m

$n=572.65$
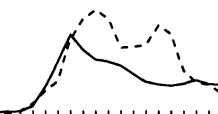

400-449 m

$\mathrm{n}=776.66$

450-499 m m
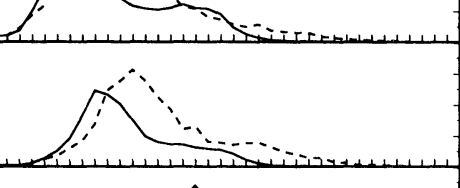

$250-299$
$n=79.8$

$$
\text { (1) }
$$

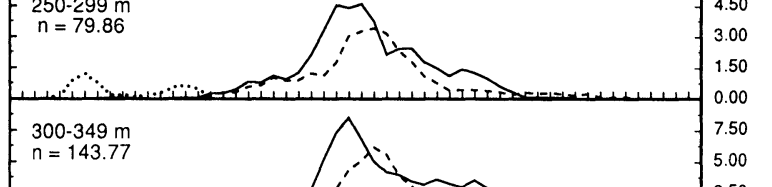

$n=143.77$

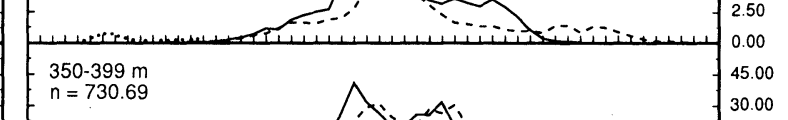

$n=730.69$

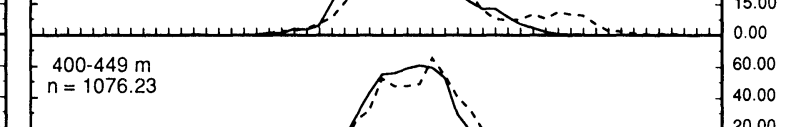

$n=1076.23$
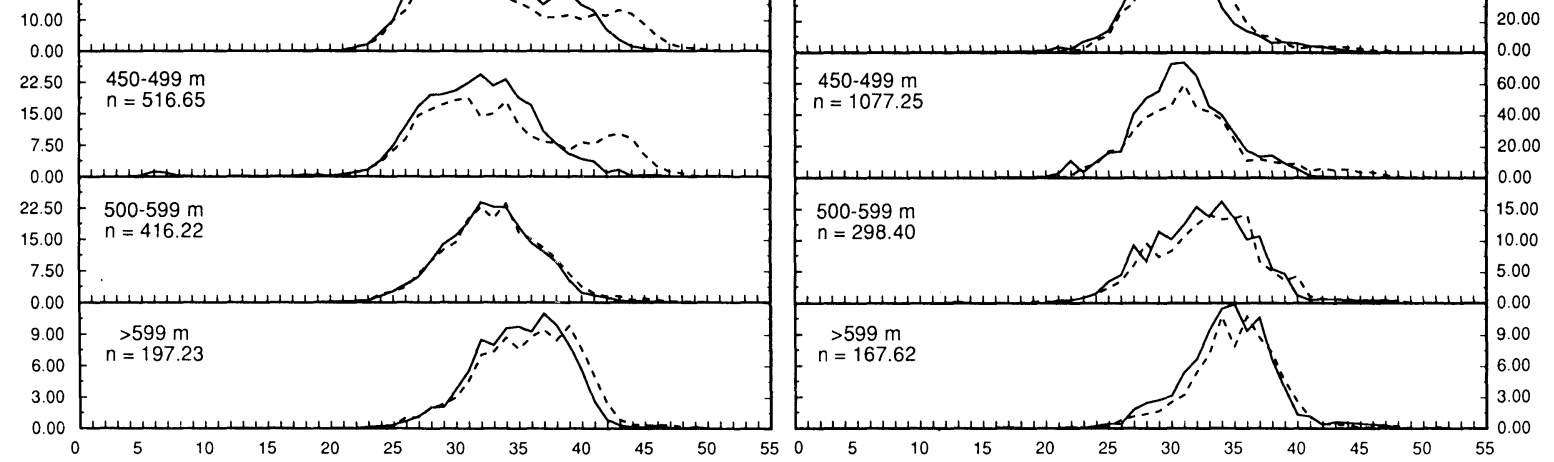

Fork length $(\mathrm{cm})$

Fig. 7. Length frequencies (sexed) of beaked redfish by depth range in each quarter in NAFO Div. 3L. 


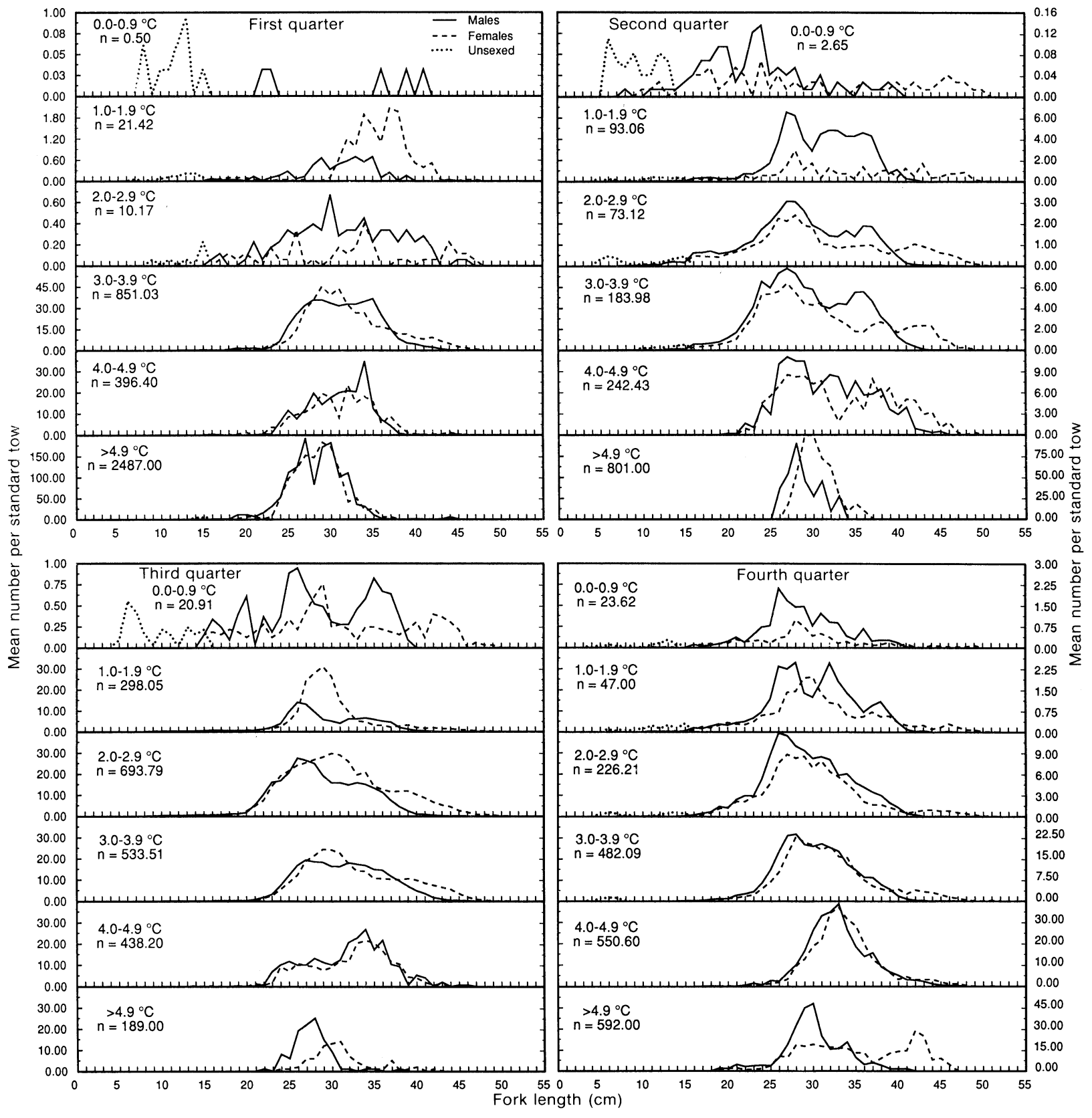

Fig. 8. Length frequencies (sexed) of beàked redfish by temperature range in each quarter in NAFO Div. 3L.

As was noted in the introduction, redfish in Div. 3L are comprised of two species. Whether or not the seasonal movements in this area are different for the two is unknown at present and will require further investigation. These investigations should be done in conjunction with any study of appropriate management units.

\section{Acknowledgements}

Appreciation is expressed to all staff involved, over the years, in the collection of all biological material used in this paper. Gratitude is also expressed to Dr G. Lilly and two anonymous reviewers for their valuable comments concerning the manuscript. 
sciences. McGraw-Hill Book Company, New York, New York, USA.

SIDORENKO, I. N. MS 1966. Distribution of redfish, Sebastes mentella Travin, at different depths of the north Newfoundland Shelf. ICNAF Res. Doc., No. 52, Serial No. $1662,16 \mathrm{p}$.

SOROKEN, V.P. 1961. The redfish; gametogenesis and migrations of the Sebastes marinus (L.) and Sebastes mentella Travin. ICNAF Spec. Publ., 3: 245-250.

TEMPLEMAN, W. 1955. Summary of Canadian researches, 1954, Subareas 2 and 3. ICNAF Ann. Proc., 5: 19-20.
1957. Redfish exploration north of Flemish Cap. Fish. Res. Board Can., Atlant. Prog. Rep., 67: 14-18.

1959. Redfish distribution in the North Atlantic. Bull. Fish. Res. Board Can., 120, 173 p.

1976. Biological and oceanographic background of Flemish Cap as an area for research on the reasons for year-class success and failure in cod and redfish. ICNAF Res. Bull., 12: 91-117.

TRAVIN, V., K. JANOULOV, A. POSTOLAKY, and G. ZAHAROV, 1961. Redfish stock distribution in the ICNAF area. ICNAF Ann. Proc., 11: 87-89. 


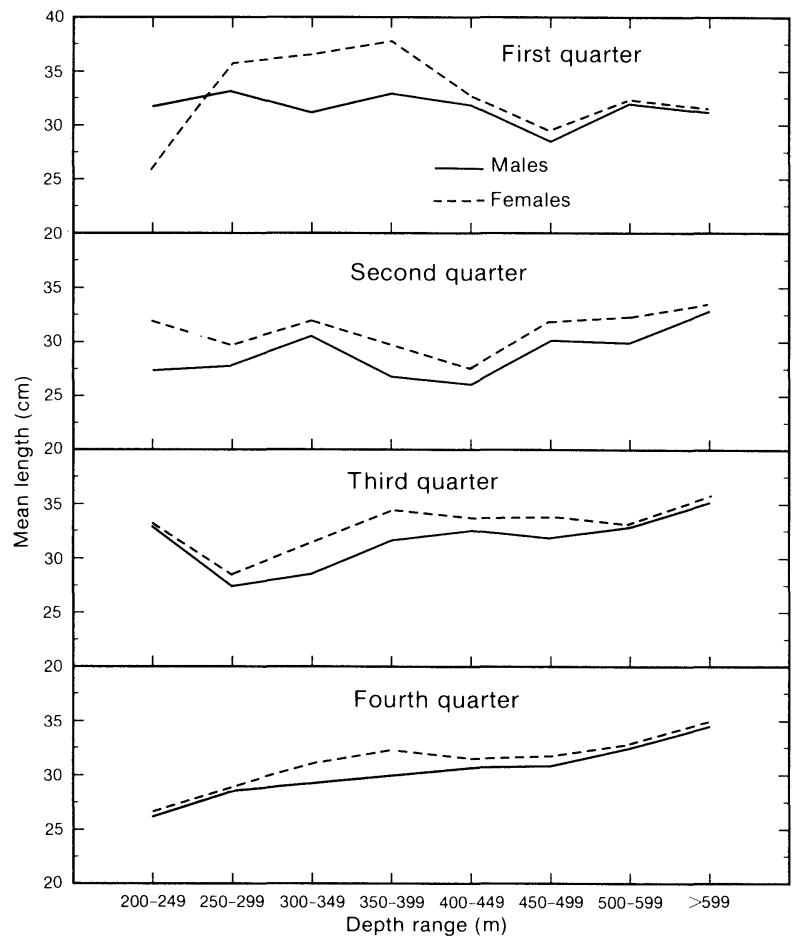

Fig. 9. Mean length of beaked redfish $\geqslant 15 \mathrm{~cm}$ by depth range in each quarter in NAFO Div. $3 \mathrm{~L}$.

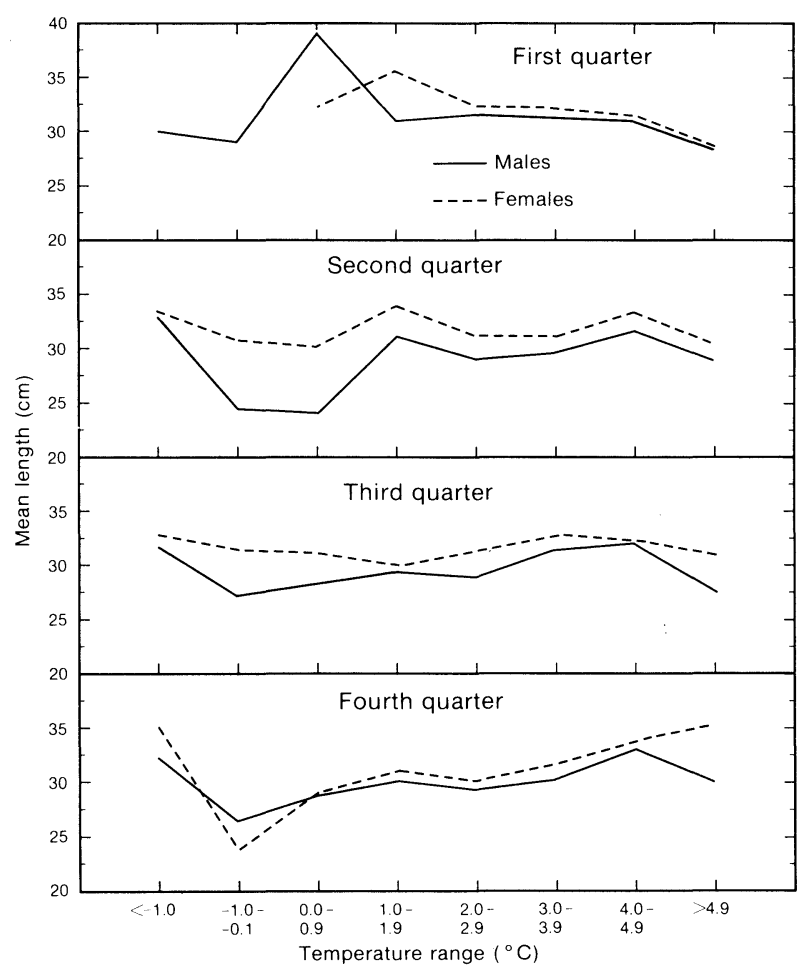

Fig. 10. Mean length of beaked redfish $\geqslant 15 \mathrm{~cm}$ by temperature range in each quarter in NAFO Div. $3 \mathrm{~L}$.

\section{References}

ATKINSON, D. B. 1984. Distribution and abundance of beaked redfish in the Gulf of St. Lawrence, 1976-1981. J. Northw. Atl. Fish. Sci., 5: 189-197.

CARROTHERS, P. J. G. MS 1974. Descriptions of trawl-gear used for demersal fish species by the Canadian fleet in Subarea 5 and Statistical Area 6 during the period 1969 through 1977. ICNAF Res. Doc., No. 28, Serial No. 3175, $12 \mathrm{p}$.

CHEKOVA, V. A. 1972. Vertical distribution of beaked redfish (Sebastes mentella Travin) according to depths on the Flemish Cap Bank. Trudy PINRO, Murmansk, 28: 199-209 (Fish. Res. Board Transl. Ser., No. 2504, 1973).

CHEKOVA, V. A., and K. G. KONSTANTINOV. 1978. Characteristics of beaked redfish, Sebastes mentella Travin, in bottom and midwater trawl catches on Flemish Cap. ICNAF Sel. Papers, 3: 17-21.

GUNDERSON, D. R. 1971. Reproductive patterns of Pacific ocean perch (Sebastodes alutus) off Washington and British Columbia and their relation to bathymetric distribution and seasonal abundance. J. Fish. Res. Board Can., 14: 417-425.

MAGNÚSSON, J. 1955. Microscopical anatomical investigations on reproduction in redfish (Sebastes marinus Linne.). Z. Zellforsch., 43: 121-167. (Fish. Res. Board Can. Transl. Ser., No. 138, 1958).

1961. Sex ratio of catches of redfish and migration. ICNAF Spec. Publ., 3: 251-252.

MARTI, Yu. Yu. 1962. Some similarities and differences in conditions under which boreal fish species exist in the Northwest and Northeast Atlantic. In: Soviet Fisheries Investigations in the Northwest Atlantic, VNIRO-PINRO, Moscow, p. 55-67 (Transl. for U.S. Dept. Int. Nat. Sci. Found., Washington, D.C. by Israel Prog. Sci. Transl., 1963).

MINET, J. P. MS 1975. Seasonal variation in the biomass of the main commercial species from surveys on St. Pierre Bank, 1971-1972. ICNAF Res. Doc., No. 72, Serial No. 3556, 8 p.

NI, I-H. 1981. Separation of sharp-beaked redfish, Sebastes fasciatus and S. mentella, from northeastern Grand Bank by morphology of extrinsic gasbladder musculature. J. Northw. Atl. Fish. Sci., 2: 7-12.

NI, I-H., and W. TEMPLEMAN. 1985. Reproductive cycles of redfishes (Sebastes) in southern Newfoundland waters. J. Northw. Atl. Fish. Sci., 6: 57-63.

NIKOLSKAYA, T. L. 1973. Distribution of beaked redfish (Sebastes mentella Travin) by depth in areas off Newfoundland and south Labrador. ICNAF Redbook, 1973(III): 53-57.

PAYNE, R. H., and I-H. NI. 1982. Biochemical population genetics of redfishes (Sebastes) off Newfoundland. J. Northw. Atl. Fish. Sci., 3: 169-172.

PERLMUTTER, A. 1953. Population studies of the rosefish. Transl. N.Y. Acad. Sci., Ser. 2, 15(5): 189-191.

SANDEMAN, E. J. MS 1956. Appendix No. 1: Hermitage Bay area. In: Annual Report of the Newfoundland Fisheries Research Station, 1955: 1-9.

SCHROEDER, W. C. 1955. Report on the results of exploratory otter trawling along the continental shelf and slope between Nova Scotia and Virginia during the summers of 1952-1953. Deep-Sea Res., Suppl. to Vol. 3: 358-372.

SIEGEL, S. 1956. Nonparametric statistics for the behavioral 